\title{
Sexual activity of different gilt genotype groups of the Pulawska breed during oestrus
}

\author{
MAREK BABICZ, MARCIN PASTWA, EWA SKRZYPCZAK*, \\ IWONA ŁUSZCZEWSKA-SIERAKOWSKA ${ }^{* *}$, AGATA WAWRZYNIAK ${ }^{* * *}$
}

Institute of Animal Breeding and Biodiversity Protection, Sub-Department of Pig Breeding and Biotechnology,

Faculty of Biology, Animal Sciences and Bioeconomy, University of Life Sciences, ul. Akademicka 13, 20-950, Lublin, Poland

*Department of Animal Breeding and Product Quality Assessment, Faculty of Veterinary Medicine and Animal Science, Poznań University of Life Sciences, Złotniki, ul. Słoneczna 1, 62-002 Suchy Las, Poland

${ }^{* *}$ Chair of Human Anatomy, Department of Normal Anatomy, Medical University of Lublin, ul. Jaczewskiego 4, 20-090 Lublin, Poland

${ }^{* * * D e p a r t m e n t ~ o f ~ M o r p h o l o g i c a l ~ S c i e n c e s, ~ S u b-D e p a r t m e n t ~ o f ~ H i s t o l o g y ~ a n d ~ E m b r y o l o g y, ~ F a c u l t y ~ o f ~ M e d i c i n e, ~}$ University of Rzeszów, ul. Leszka Czarnego 4, 35-615 Rzeszów, Poland

Babicz M., Pastwa M., Skrzypczak E., Łuszczewska-Sierakowska I., Wawrzyniak A. Sexual activity of different gilt genotype groups of the Pulawska breed during oestrus

Summary

The aim of the study was to analyze sexual activities of gilts representing various genotype groups in the RBP4 and MC4R locus.

Observations of gilt behaviour during the first and the second oestrus (before initiation of the reproduction phase) were carried out in the Pulawska breed from conservation breeding. The evaluation process comprised the duration of the heat as well as the intensity of heat behaviours. Polymorphism identification in RBP4 (SNP: rs55618789) and MC4R (SNP: rs81219178) genes was performed, which resulted in the identification of three (MC4R: AA, AG and GG) and two (RBP4: CC and CT) gilt genotype groups. Significantly varying sexual activities were observed: the most intensive heat symptoms were demonstrated by $C T$ gilts in the course of the first $(\mathrm{P} \leq \mathbf{0 . 0 5})$ and second $(\mathrm{P} \leq \mathbf{0 . 0 1})$ oestrus (locus $\mathrm{RBP4})$ reaching, on average, $2.15 \pm 0.13$ and $2.52 \pm 0.13 \mathrm{pt}$. It was further determined that the heats of $C T$ gilts lasted longer and this difference, in the second heat, was significant $(\mathrm{P} \leq 0.01)$. In the case of the MC4R locus, significant differences in gilt sexual activities were observed only in the course of the second oestrus $(P \leq 0.05)$. In addition, a strong association was also demonstrated of AA (locus MC4R) and CC (locus RBP4) genotypes with the thickness of the subcutaneous fat tissue $(\mathrm{P} \leq \mathbf{0 . 0 5})$ amounting in these gilts to $11.57 \pm 0.21 \mathrm{~mm}$ and $11.50 \pm 0.19 \mathrm{~mm}$, respectively.

Keywords: Pulawy breed, MC4R gene, sow sex activity, gene polymorphism

One of the conditions of high efficiency in pig production is successful reproduction. The use of high meatiness gilts and sows in mass breeding often causes a lack of or low intensity of typical sexual behaviour in heat which has a negative influence on the reproduction rate (7).

Mating behaviour in pigs is observed for a short period of time and occurs at the moment of contact of a boar and a sow in heat. The sow plays a prominent role, sending signals toward the boar. During mating the boar sniffs the sow, directs his nose at her body, moves its snout along the sides and close to the vulva, producing a series of throaty grunts being a component part of courtship. The increasing tactile stimulation of the sow also heightens the sexual arousal of the boar (4).

The moment at which the sow exhibits full tolerance to the boar (the so called lordosis reflex) shows the peak of the heat period and the optimal time for mating or insemination. The appropriate identification of oestrus symptoms in sows is hindered by the so called 'silent heats'. Their occurrence is initiated, among other things, by stress stimuli which may provoke masking of sexual behaviours $(1,2,7)$.

Current research indicates that the intensity of sexual behaviour (8) as well as the age at which females show external manifestations of sexual activity (9) is conditioned genetically. Identifying the association 
between DNA polymorphism and sexual activity of gilts could be one of the ways of limiting problems related to reproduction.

The aim of the study was to analyze sexual activities of gilts representing various genotype groups in the RBP4 and MC4R locus.

\section{Material and methods}

Animals. Research was conducted on 72 gilts of the Pulawska breed (conservation breeding). All animals were subject to veterinary prevention, husbandry conditions adhered to animal welfare standards, feeding was adjusted to the age and the physiological condition of the animals according to animal feeding standards (6). Sexual activity

Tab. 1. Association of RBP4 SNP with sexual activity in Pulawska breed $(\mathrm{LSM} \pm \mathrm{SE})$

\begin{tabular}{|l|r|r|}
\hline \multicolumn{1}{|c|}{ Trait } & \multicolumn{2}{|c|}{ RBP4 } \\
\hline IOE & \multicolumn{2}{|c|}{ CT } \\
\hline AG (days) & $206.33 \pm 2.88$ & $204.85 \pm 1.67$ \\
BW (kg) & $83.77 \pm 1.97$ & $85.56 \pm 1.14$ \\
DH (days) & $2.22 \pm 0.20$ & $2.26 \pm 0.12$ \\
IOS (pt.) & $1.56^{\mathrm{a}} \pm 0.23$ & $2.15^{\mathrm{b}} \pm 0.13$ \\
IIOE & & \\
\hline AG (days) & $226.56 \pm 2.91$ & $225.48 \pm 1.68$ \\
BW (kg) & $98.22 \pm 2.16$ & $100.44 \pm 1.25$ \\
\hline DH (days) & $2.11^{\mathrm{A}} \pm 0.19$ & $2.70^{\mathrm{B}} \pm 0.11$ \\
IOS (pt.) & $1.56^{\mathrm{A}} \pm 0.22$ & $2.52^{\mathrm{B}} \pm 0.13$ \\
\hline
\end{tabular}

Explanations: means in rows designated with different letters differ significantly at $P \leq 0.01(\mathrm{~A}, \mathrm{~B})$ and $P \leq 0.05(\mathrm{a}, \mathrm{b})$; IOE and IIOE - first and consecutive oestrus (before reproduction phase); $\mathrm{AG}$ - age of gilts at the beginning of heat 1 and 2; BW - body weight of sows determined for heat 1 and $2 ; \mathrm{DH}$ - duration of heat 1 and 2; IOS - intensity of oestrus symptoms in 3-point scale (Tab. S1) for heat 1 and 2

Tab. 2. Scale of intensity assessment of heat symptoms in sows (Stasiak, 1996)*

\begin{tabular}{|l|l|}
\hline \multicolumn{1}{|c|}{ Points } & \multicolumn{1}{|c|}{ Level of observed symptoms in descriptive form } \\
\hline $\mathbf{3}$ pcts. & $\begin{array}{l}\text { Very clear oestrus symptoms, response to testing-boar and } \\
\text { attempt to mate } \geq \mathbf{2 6 ~ s}\end{array}$ \\
$\mathbf{2}$ pcts. & $\begin{array}{l}\text { Clear oestrus symptoms, response to testing-boar and attempt } \\
\text { to mate } \geq \mathbf{6}-\mathbf{2 5} \leq \mathrm{s}\end{array}$ \\
$\begin{array}{l}\text { Poor oestrus symptoms, response to testing-boar and attempt } \\
\text { to mate } \leq \mathbf{5 ~ s}\end{array}$ \\
\hline
\end{tabular}

Explanations: * assessment of heat symptoms according to Stasiak (10) in our own modification

Tab. 3. Primer details for the SNPs genotyped in this study

\begin{tabular}{|c|c|c|c|c|c|}
\hline Gene & SNP & Forward and Reverse primers $\left(5^{\prime}->3^{\prime}\right)$ & Product PCR (bp) ${ }^{*}$ & $\mathrm{ER}^{* *}$ & Sequence \\
\hline RBP4 & $\begin{array}{l}\text { SNP: rs55618789 } \\
\text { c.156C>T, p.(=) }\end{array}$ & $\begin{array}{l}\text { F 5'-GCACAGTCCCTCTCCCCTCCC-3' } \\
\text { R 5'-GGGATGAGCGGGATCGGGGT-3' }\end{array}$ & 552 & Hinfl & NC_010456.4 \\
\hline MC4R & $\begin{array}{l}\text { SNP: rs81219178 } \\
\text { c.1426A>G (p.Asp298Asn) }\end{array}$ & $\begin{array}{l}\text { F 5'-TCACAGAGGCCACCCAGGGGATA-3' } \\
\text { R 5'-ACTGGCACCATCCGCCAAGG-3' }\end{array}$ & 287 & Taql & NC_010443.4 \\
\hline
\end{tabular}

Explanations: * base pair; ** restriction enzyme (Thermo Fisher Scientific Inc, USA) observations were carried out in the course of the first and the second heats. The activity during oestrus was evaluated on the basis of the intensity of heat symptoms and the duration of the lordosis reflex (Tab. 2). The observation of gilts behaviour was carried out twice a day: in the morning and in the afternoon (the results are shown in tables as average of both observations. The observations were performed by trained employees of the pig farm). The starting point for the proper measuring period was defined as the manifestation of the first signs of oestrus, i.e. restless behaviour, swelling of the vulva, jumping onto other females, reaction to the testing-boar. In order to establish the precise moment when the oestrus begins control observations were performed 1 day before the predicted oestrus based on the calendar. During the observation all the gilts were marked in a visible place on their backs in a manner enabling easy identification.

Detected polymorphism. Synonymous substitution (c.156C $>$ T, p. $(=)$ ) of the RBP4 (SNP: rs55618789) and nonsynonymous substitution (c.1426A $>$ G, p.Asp298Asn) of the MC4R (SNP: rs81219178) were identified using the HinfI and TaqI enzymes, respectively (Tab. 3). A and G alleles as well as AA, AG and GG genotypes (MC4R locus) and $\mathrm{C}$ and $\mathrm{T}$ alleles as well as CC and CT genotypes (RBP4 locus) were identified in the examined population of gilts.

Statistical analysis. For the examined population, frequency of allele and genotype occurrence in the RBP4 and $M C 4 R$ loci were calculated and the conformity analysis of genotype distribution in the population with that expected on the basis of Hardy-Weindberg trait distribution law was carried out. The analysis of utility indicators was carried out employing ANOVA multifactorial analysis of variance by the least squares method in accordance with the GLM-SAS x.9.3. procedure (2014) following the adopted linear model:

$$
y_{i j k l}=\mu+R B P 4_{i}+M C 4 R_{j}+r_{k}+m_{l}++e_{i j k l m}
$$

where: $y_{i j k l}-$ trait phenotypic value; $\mu$-population average; $R B P 4$ - constant genotype effect in the examined locus $(i=1,2)$; $M C 4 R_{j}$ - constant genotype effect in the examined locus $(i=1,2,3) ; r_{k}-$ constant heat effect $(j=1,2)$; $m$ - constant lactation effect $(\mathrm{k}=1,2) ; e_{i j k l m}$-random error. The results were presented as least square means (LSM) and standard errors (SE). Differences between level means of experimental factors were analysed by Duncan test of multiple comparisons.

\section{Results and discussion}

The frequency of alleles and genotypes of the examined gilt population is shown in Table 3 . The RBP4 SNP had a strong association with the intensity of oestrus symptoms in the first $(P \leq 0.05)$ and the second heat $(P \leq 0.01)$. The analysis of sexual activity revealed that CT homozygotes manifested heat symptoms more intensively than the remaining females (Tab. 1), received 
$2.15 \pm 0.13$ and $2.52 \pm 0.13$ points in the first and the second heat, respectively against $1.56 \pm 0.23$ and 1.56 \pm 0.22 pt. (CC sows received 1.56 points in both heats). In addition, the oestrus of $\mathrm{CT}$ gilts was longer (differences between genotypes were significant at $P \leq 0.01$ in the second oestrus), despite the fact that, at the moment of the occurrence of symptoms, they were younger than sows from the remaining genotype groups.

For the MC4R locus (Tab. 4), significant associations were found to occur only during the second heat $(P \leq 0.05)$, with the best results recorded for AA gilts ( $2.86 \pm 0.27$ pt.).

Moreover, significant differences $(P \leq 0.05)$ were demonstrated between gilt genotype groups in backfat thickness, with the thickest backfat recorded in gilts with CC (SNP: rs55618789) and AA (SNP: rs81219178) genotypes (Tab. 5 and 6). CT group (locus $R B P 4)$ was also characterised by a higher meatiness than CC gilts $(P \leq 0.05)$.

Ploeg van der et al. (8) reported an association of MC4R with the control of feed intake and energy expenditure; in addition, they observed an influence of MC4R on the sexual behaviour and erection modulation in rodents. On the other hand, Friebe et al. (5) demonstrated a considerable increase of RBP4 protein secretion with age and attainment of sexual maturity in children, which indicates that it plays a role in the process of maturation. RBP4 level was found to be correlated, among other things, with growth, body weight or BMI index.

On the other hand, Rens van and Lende van der (9), examining associations between prolactin receptor gene polymorphism and reproduction rate, showed that during insemination $\mathrm{BB}$ genotype gilts were significantly $(P \leq 0.05)$ younger than AA genotype gilts: on average 41 days younger in the first heat and 49 days during the first insemination.

The results presented in the study appear interesting in the context of investigations conducted by Stasiak et al. $(10,11)$ who demonstrated varying levels of sexual activity in sows of different breeds. In the presented study, the authors demonstrated that Pulawska breed sows obtained a higher assessment of their sexual activity than sows of Large Polish White and White Polish Landrace. In addition, a boar tolerance reflex appeared earlier in sows of the Pulawska breed.

Much attention so far has been devoted to the analysis of polymorphism association in RBP4 and $M C 4 R$ genes with values of production and reproduction indices in swine. Studies conducted by Davoli et al. (3) showed significant differences $(P \leq 0.05 ; P \leq 0.01)$ between AA and GG homozygotes (locus $M C 4 R$ ) in daily body weight gains, feed conversion ratio, ham $(\mathrm{LSM} \pm \mathrm{SE})$
Tab. 4. Association of $M C 4 R$ SNP with sexual activity in Pulawska breed (LSM \pm SE)

\begin{tabular}{|c|c|c|c|}
\hline \multirow{2}{*}{ Trait } & \multicolumn{3}{|c|}{ MC4R } \\
\hline & $A A$ & AG & GG \\
\hline \multicolumn{4}{|l|}{ IOE } \\
\hline AG (days) & $201.71 \pm 3.20$ & $204.84 \pm 1.94$ & $208.40 \pm 2.68$ \\
\hline BW (kg) & $82.46 \pm 2.22$ & $85.57 \pm 1.35$ & $86.08 \pm 1.86$ \\
\hline DH (days) & $2.43 \pm 0.22$ & $2.37 \pm 0.13$ & $1.90 \pm 0.18$ \\
\hline IOS (pt.) & $2.57 \pm 0.26$ & $1.89 \pm 0.16$ & $1.78 \pm 0.21$ \\
\hline \multicolumn{4}{|l|}{ IIOE } \\
\hline AG (days) & $222.14 \pm 3.22$ & $225.42 \pm 1.96$ & $228.90 \pm 2.70$ \\
\hline BW (kg) & $97.71 \pm 2.48$ & $100.63 \pm 1.50$ & $100.00 \pm 2.07$ \\
\hline DH (days) & $2.71 \pm 0.23$ & $2.47 \pm 0.14$ & $2.60 \pm 0.20$ \\
\hline IOS (pt.) & $2.86^{a} \pm 0.27$ & $1.85^{b} \pm 0.16$ & $2.50 \pm 0.22$ \\
\hline
\end{tabular}

Explanations: $\mathrm{a}, \mathrm{b}-\mathrm{P} \leq 0.05 ; \mathrm{AG}, \mathrm{BW}, \mathrm{DH}, \mathrm{IOS}-$ as in Tab. 1

Tab. 5. Association of RBP4 SNP with carcass traits in Pulawska breed

\begin{tabular}{|c|c|c|c|}
\hline \multirow{2}{*}{\multicolumn{2}{|c|}{ Trait }} & \multicolumn{2}{|c|}{ RBP4 } \\
\hline & & CC & СT \\
\hline \multicolumn{4}{|c|}{ Production indices of sows* } \\
\hline \multicolumn{2}{|r|}{ Daily body weight gains of sows ( $g$ ) } & $556.00 \pm 23.32$ & $549.67 \pm 13.47$ \\
\hline \multicolumn{2}{|c|}{ Backfat thickness on back (mm) } & $11.50^{\mathrm{a}} \pm 0.19$ & $11.06^{b} \pm 0.11$ \\
\hline \multicolumn{2}{|c|}{ Meatiness of sows (\%) } & $56.21^{\mathrm{a}} \pm 0.31$ & $56.96^{b} \pm 0.19$ \\
\hline \multicolumn{4}{|c|}{ Reproduction indices of sows** } \\
\hline \multirow{4}{*}{ 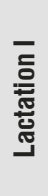 } & Number of piglets born in litter (heads) & $10.56 \pm 0.41$ & $10.85 \pm 0.24$ \\
\hline & Number of piglets on day 21 of life (heads) & $9.56 \pm 0.38$ & $9.63 \pm 0.22$ \\
\hline & Mass of piglet when born $(\mathrm{g})$ & $1312.22 \pm 58.79$ & $1262.96 \pm 33.94$ \\
\hline & Mass of piglet on day $21 \mathrm{~g}$ ) & $5262.22 \pm 263.42$ & $5445.19 \pm 152.09$ \\
\hline \multirow{4}{*}{ 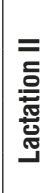 } & Number of piglets born in litter (heads) & $10.89 \pm 0.59$ & $11.56 \pm 0.34$ \\
\hline & Number of piglets on day 21 of life (heads) & $9.78 \pm 0.42$ & $10.44 \pm 0.24$ \\
\hline & Mass of piglet when born $(\mathrm{g})$ & $1351.59 \pm 60.55$ & $1300.85 \pm 34.96$ \\
\hline & Mass of piglet on day $21(\mathrm{~g})$ & $5420.09 \pm 271.32$ & $5608.54 \pm 156.65$ \\
\hline
\end{tabular}

Explanations: data in rows designated with different letters $(a, b)$ differ significantly at $P \leq 0.05$; * production indices of sows determined prior to the reproduction phase (before I lactation); ** reproduction indices determined for the first and second litters of sows (lactations I and II)

mass and backfat thickness in pigs, with greater values determined in AA homozygotes. In their studies, Szyndler-Nędza et al. (13) as well as Szyndler-Nędza et al. (12) reported similar correlations and, in addition, determined a significant variability of reproduction indicators where AA homozygotes (locus MC4R) were characterised by a higher mean number of piglets born and reared up to day 21 of life in comparison with the remaining genotype sow groups. Terman et al. (14) reported a strong polymorphic association in the MC4R locus with the total number of born piglets, number of piglets born alive $(P \leq 0.05$, for litters 1 and 2) and the number of piglets reared up to day 21 $(P \leq 0.01$, for litter 1$)$ between sow genotype groups, with homozygotes recording higher results. 
Tab. 6. Association of $M C 4 R$ SNP with carcass traits in Pulawska breed (LSM $\pm \mathrm{SE})$

\begin{tabular}{|c|c|c|c|c|}
\hline \multirow{2}{*}{\multicolumn{2}{|c|}{ Trait }} & \multicolumn{3}{|c|}{ MC4R } \\
\hline & & AA & AG & GG \\
\hline \multicolumn{5}{|c|}{ Production indices of sows* } \\
\hline \multicolumn{2}{|c|}{ Daily body weight gains of sows (g) } & $531.71 \pm 26.59$ & $557.00 \pm 16.14$ & $554.00 \pm 22.25$ \\
\hline \multicolumn{2}{|c|}{ Backfat thickness on back (mm) } & $11.57^{\mathrm{a}} \pm 0.21$ & $11.18 \pm 0.13$ & $10.85^{b} \pm 0.18$ \\
\hline \multicolumn{2}{|c|}{ Meatiness of sows (\%) } & $56.53 \pm 0.31$ & $56.77 \pm 0.19$ & $56.96 \pm 0.26$ \\
\hline \multicolumn{5}{|c|}{ Reproduction indices of sows** } \\
\hline \multirow{4}{*}{ 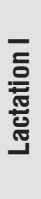 } & Number of piglets born in litter (heads) & $11.43 \pm 0.46$ & $10.63 \pm 0.28$ & $10.60 \pm 0.38$ \\
\hline & Number of piglets on day 21 of life (heads) & $10.29 \pm 0.42$ & $9.47 \pm 0.25$ & $9.40 \pm 0.35$ \\
\hline & Mass of piglet when born $(\mathrm{g})$ & $1237.14 \pm 65.78$ & $1251.05 \pm 39.93$ & $1348.00 \pm 55.04$ \\
\hline & Mass of piglet on day 21 (g) & $5145.71 \pm 300.50$ & $5433.68 \pm 182.40$ & $5512.00 \pm 251.42$ \\
\hline \multirow{4}{*}{ 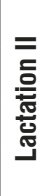 } & Number of piglets born in litter (heads) & $11.71 \pm 0.68$ & $11.37 \pm 0.41$ & $11.20 \pm 0.57$ \\
\hline & Number of piglets on day 21 of life (heads) & $10.71 \pm 0.49$ & $10.32 \pm 0.29$ & $9.90 \pm 0.41$ \\
\hline & Mass of piglet when born $(g)$ & $1274.26 \pm 67.76$ & $1288.58 \pm 41.13$ & $1388.44 \pm 56.69$ \\
\hline & Mass of piglet on day 21 (g) & $5300.09 \pm 309.52$ & $5596.69 \pm 187.87$ & $5677.36 \pm 258.96$ \\
\hline
\end{tabular}

Explanations: as in Tab. 5

Recapitulating, recognition of the appropriate moment for artificial insemination or natural mating of sows is among the key elements of effective swine reproduction. Masking of sexual behaviour by females may hinder this process and decrease reproduction indices and, therefore, it appears appropriate to look for genetic factors preconditioning sexual behaviour of females. The authors' own studies showed a significantly higher $(P \leq 0.01 ; P \leq 0.05)$ intensity of heat symptoms and longer heat duration in heterozygotes $R B P 4 C T$ in comparison to gilts $R B P 4 C C$, as well as of homozygotes $M C 4 R A A$ in comparison to the remaining genotype groups of gilts (including locus $M C 4 R$ ). The obtained information may be used in the assessment of breeding specificity of Pulawska breed pigs, as well as in MAS selection for pigs.

\section{References}

1. Babicz M., SkrzypczakE., Kropiwiec K., Kozubska-Sobocińska A., DanielakCzech B.: Impact of PRL and FST loci polymorphism on sexual activity of Pulawska gilts. Ann. Anim. Sci. 2014, 14, 4, 821-830.

2.Babicz M., Rejduch B., Kozubska-Sobocińska A., Pastwa M., Kasprzyk A., Stasiak A., Serafin-Kozak M.: Analysis of sexual activity in gilts in terms of their reproductive value. Ann. Anim. Sci. 2011, 11, 2, 241-250.

3. Davoli R., Braglia S., Valastro V., Annaratone C., Comella M., Zambonelli P. Nisi I., Gallo M., Buttazzoni L., Russo V.: Analysis of MC4R polymorphism in Italian Large White and Italian Duroc pigs: association with carcass traits. Meat Sci. 2012, 90, 887-892.

4. Ford J. J.: Differentiation of sexual behaviour in pigs. J. Reprod. Fertil Suppl. 1990, 40, 311-321.

5. Friebe D., Neef M., Erbs S., Dittrich K., Kratzsch J., Kovacs P., Blüher M., Kiess W., Körner A.: Retinol binding protein 4 (RBP4) is primarily associated with adipose tissue mass in children. Int. J. Pediatr. Obes. 2011, 6, 345-352.

6. Grela E. R., Skomial J.: Zalecenia żywieniowe i wartość pokarmowa pasz dla świń. Normy żywienia świń. IFiŻZ PAN, Jabłonna 2014.

7. Liptrap R. M.: Stress and reproduction in domestic animals. Ann. N. Y. Acad. Sci. 1993, 29, 275-284.

8. Ploeg L. H. van der, Martin W. J., Howard A. D., Nargund R. P., Austin C. P., Guan X., Drisko J., Cashen D., Sebhat I., Patchett A. A., Figueroa D. J., DiLella A. G., Connolly B. M., Weinberg D. H., Tan C. P., Palyha O. C., Pong S. S., MacNeil T., Rosenblum C., Vongs A., Tang R., Yu H., Sailer A. W., Fong T. M., Huang C., Tota M. R., Chang R. S., Stearns R., Tamvakopoulos C., Christ G.,
Drazen D. L., Spar B. D., Nelson R. J., MacIntyre D. E.: A role for the melanocortin 4 receptor in sexual function. Proc. Natl. Acad. Sci. USA 2002, 99, 17, 11381-11386.

9. Rens B. T. van, Lende T. van der: Litter size and piglet traits of gilts with different prolactin receptor genotypes. Theriogenology 2002, 57, 883-893.

10. Stasiak A.: Współzależność aktywności płciowej loszek w czasie rui z rozwojem narządów rozrodczych oraz płodnością potencjalną i rzeczywistą. Wyd. AR in Lublin 1996, 192, 1-59.

11. Stasiak A., Mazur A., Babicz M., Kamyk P.: Estimation of potential fertility of gilts of three breeds maintained in Poland. Anim. Sci. Pap. Reports 2006 , 24, 81-86.

12. Szyndler-Nędza M., Ropka-Molik K. Association of MC4R and LEPR loci with reproductive performance and milk composition of sows. Anim. Sci. Pap. Reports 2015, 33, 267-276.

13. Szyndler-Nędza M., Tyra M., Blicharski T., Piórkowska K.: Effect of mutation in MC4R gene on carcass quality in Pulawska pig included in conservation breeding programme. Anim. Sci. Pap. Reports 2010, 28, 37-45.

14. Terman A., Kmiec M., Polasik D., Rybarczyk A.: Association between RBP4 gene polymorphism and reproductive traits in polish sows. J. Anim. Vet. Adv. 2011, 10, 2639-2641

Corresponding author: Marek Babicz Ph.D., ul. Akademicka 13, 20-950, Lublin, Poland; e-mail: marek.babicz@up.lublin.pl 